\title{
reviews
}

THIS book* must fascinate everyone interested in the history of British zoology in the 19th century. It begins with Joseph Banks still in the seat of power, his soirées at 32 Soho Square attended by eminent scientists discussing the latest 'curiosities'. Over his shoulder one has a glimpse of Hans Sloane whose collections, gradually disintegrating, were housed in subterranean excavations, said to resemble the catacombs of Palermo, in Montagu House. The greatest collections remained in possession of the landed gentry and nobility; even those offered to the Government were largely refused because of lack of space in which to keep them. Appointed by patronage, the miserably paid Keepers of Natural History had neither status nor influence.

The gradual changes which led to the organisation of the greatest collections in the world occupied the whole of the Victorian era and were the work of two keepers, John Edward Gray and Albert Gunther, their lives and work here admirably surveyed by the grandson of the latter. The major events are the erection behind Montagu House of the British Museum with the transfer there of the Natural History collections in 1840 and 1841 and the far greater move, in distance and bulk of material, from Bloomsbury to South Kensington in 1882 and 1883.

Born in 1800 , the son of a struggling botanist and pharmacist, John Gray proceeded by devious occupations into medicine, to emerge, by virtue of character and ability, as a leading naturalist. Friendship with W. E. Leach, then too briefly at Montagu House, introduced him to Banks and his circle. His first Museum employment, at a daily payment of 15 shillings, was during the keepership of J. G. Children whom he succeeded in 1840. Initially, with his fellow keepers he was subject only to the Principal Librarian with direct access to the Trustees, this changing in 1856 when Richard Owen was appointed superintendant of all the natural history departments.

The spirit of Linnaeus, tempered now by that of Cuvier, prevailed and the great task presented to Gray was

*A Century of Zoology at the British Museum-Through the Lives of Two Keepers. By Albert E. Gunther. Pp. $533+37$ photographs. (Dawsons: London, 1975.) £17.30.

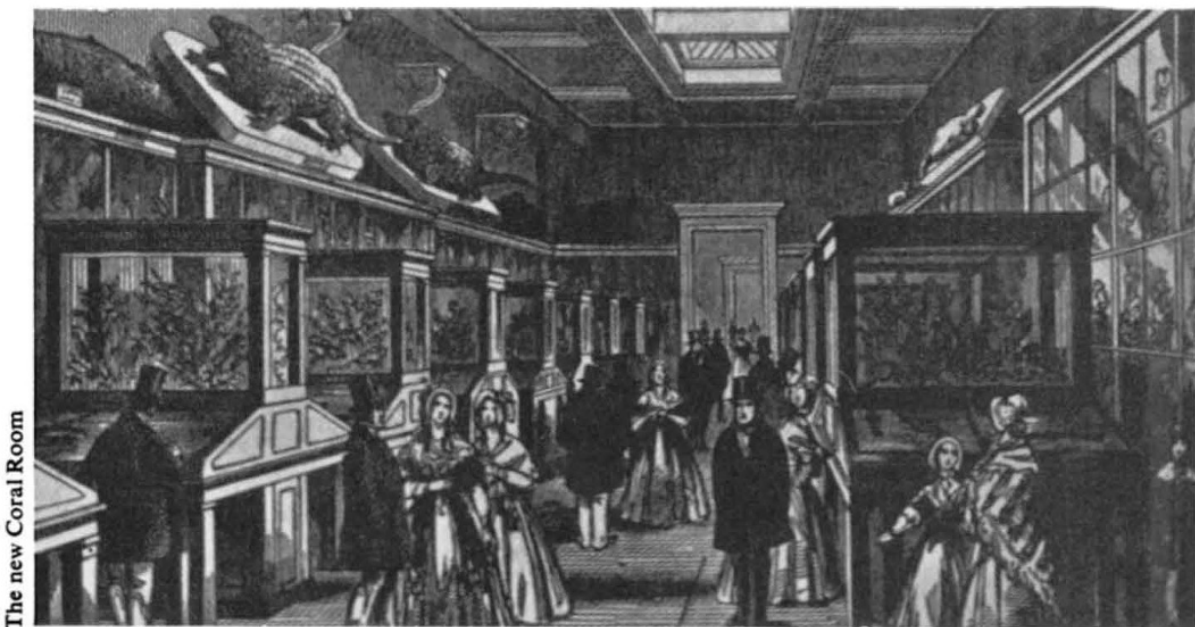

\section{Recollections of a century}

the accumulation of specimens with "the diffusion of instruction and rational amusement". He travelled widely, visiting museums and meeting their directors and staff. Material began to pour in particularly from the colonies; collections of birds were purchased from John Gould, collections of shells from Hugh Cumming. Gradually, the collections came to rival in extent that of the still growing empire, although the Admiralty and Foreign Office were to disregard its claims until the conflict over the Challenger collections led to the final deposit of these in the Museum.

The first British Museum catalogues were contained in the suitably named Naturalist's (later Zoologist's) Miscellany, begun in 1790 by Shaw and illustrated by Nodder, then briefly continued by Leach. Gray's achievement was to produce the first adequate catalogues of major groups, starting with the reptiles. But how could a handful of underpaid, badly housed assistants contend with the flood of incoming material? Wallace's complaint to Darwin about the reaction to his claim to have brought 8,000 new species from the Amazon was met with commiseration for their overwhelming task and with a feeling that "too much systematic work and description blunt the faculties".

It was to produce more order out of chaos that the young Albert Gunther, initially a theology student at Tübingen, came to the Museum in 1857 to be led into "A suite of three half subterranean rooms, in which the spirit collection was stored .. . The floor showed large damp patches. There was no ventilation. Non-inviting rheumaticky quarters at any time. But what did I care?" What indeed?-he regarded this first year working on the great Catalogue of Fishes (1859-1870) as the happiest in his life. His later friendship with Alfred Newton at Cambridge bore fruit for the enduring sustenance of all zoologists by the establishment in 1856 of the Zoological Record.

Carrying the weight of the Department during Gray's final years of illness, Gunther succeeded him in 1875 . His relations with Owen are interesting. Initially very much the protégé, differences developed alongside increased responsibilities, notably in connection with the new Museum at South Kenresponsible although the final plans were made without the knowledge of the keepers (or indeed of Owen himself). This is no place to discuss either ning of a building into which Gunther had to move specimens for the custody of which he was responsible although "their selection and arrangement was to be left to the Superintendent."

That figure was almost immediately replaced by the first appointed director, William Flower, who also assumed the keepership when Gunther retired in 1895 , to be succeeded in this capacity by Sydney Harmer with Tate Regan as a junior member of staff. Here this zoologists of my generation came into the picture. sington for which Owen was fully the architecture or the internal planbook ends-not far short of when 